\title{
PENINGKATAN KINERJA GURU MATEMATIKA DALAM PEMBELAJARAN MELALUI SUPERVISI KOLABORATIF DI SMP NEGERI 1 MERAWANG
}

\author{
Andriana Marsianti \\ SMP Negeri 1 Merawang \\ amarsianti@gmail.com
}

\begin{abstract}
Abstrak
Penelitian ini bertujuan untuk meningkatkan kinerja guru Matematika dalam pembelajaran melalui supervisi kolaboratif. Penelitian ini berbentuk Penelitian Tindakan Sekolah yang dilakukan dalam dua siklus. Setiap siklus dilaksanakan dengan empat langkah, yakni perencanaan, tindakan, pengamatan, dan refleksi. Tindakan dilakukan dua pertemuan persiklus. Setiap pertemuan dilakukan tahapan supervisi kolaboratif yaitu pra-observasi, observasi pembelajaran, pasca-observasi, analisis data, pemberian umpan balik, dan pemberian tindak lanjut. Data penelitian berupa hasil pengamatan di lapangan dan dokumentasi. Instrumen pengumpulan data adalah pedoman observasi dan dokumentasi. Analisis data dilakukan dengan teknik kualitatif dan kuantitatif. Hasil penelitian setiap siklus menunjukkan adanya peningkatan kinerja guru Matematika dalam pembelajaran. Peningkatannya dapat dilihat dari skor rata-rata kinerja siklus I dan siklus II. Skor rata-rata kinerja guru sebesar 70,71 pada siklus I dan pada siklus II mencapai 88,89. Dengan demikian, dapat disimpulkan, bahwa supervisi kolaboratif dapat meningkatkan kinerja guru Matematika dalam pembelajaran di SMP Negeri 1 Merawang. Kata Kunci: Kinerja Guru; Supervisi Akademik; Pendekatan Kolaboratif.
\end{abstract}

\begin{abstract}
This study intends to improve the performance of mathematic teachers in learning through collaborative academic supervision. This research had the form of School Action Research which was conducted in two cycles. Each cycles is taken place in four steps, namely planning, acting, observing, and reflecting. The action was taken place in two cycle meeting. Each meeting taken place the collaborative supervision stages, namely pre-observation, learning observation, post-observation, data analysis of supervision, providing feedback, and providing follow-up. The research data had the form of observations in the field and documentation. The instrument of the main data collection was observation and documentation. Data analysis was showed by using qualitative and quantitative tehnique. The result of each cycle showed an increase in the performance of mathematic teachers in learning. The increase was able to be seen from the average performance score of cycle I and cycle II. The average of teachers performance assesment was 68.00 in cycle I and it reached 88,89 in cycle II. Thus, it was able to conclude that collaborative supervision can improve the performance of Mathematic teachers in learning at SMP Negeri 1 Merawang.
\end{abstract}

Keywords : Teacher Performance; Academic Supervision; Collaborative Approach.

\section{Pendahuluan}

Matematika merupakan mata pelajaran yang termasuk di dalam muatan kurikulum SMP. Materi pembelajaran Matematika merupakan materi pembelajaran yang tidak disukai oleh kebanyakan siswa. Semakin tinggi jenjang kelas maka materinya semakin sulit. Hal ini bisa berakibat pada penurunan minat dan motivasi belajar siswa. Bila minat dan motivasi belajar siswa rendah akan mengakibatkan hasil belajar yang rendah pula. 
Sebagai seorang guru yang mengajar Matematika, maka mutu kegiatan pembelajaran Matematika menjadi tanggung jawab dan tugasnya sebagai pendidik. Menurut Undang-Undang Nomor 14 Tahun 2005 tentang Guru dan Dosen pasal 1 ayat 1[1], dijelaskan bahwa guru merupakan pendidik profesional dengan tugas utama mendidik, mengajar, membimbing, mengarahkan, melatih, menilai, dan mengevaluasi peserta didik. Tugas guru yang dimaksud dalam undang-undang tersebut termasuk juga untuk tugas guru Matematika.

Mengingat tugas guru yang telah ditetapkan oleh undang-undang tersebut sangat kompleks maka seorang guru Matematika harus selalu menaikkan kompetensi profesionalnya secara berkesinambungan dan tiada henti untuk mengikuti perkembangan ilmu pengetahuan dan kerangka berpikir baru di bidang pembelajaran agar kegiatan pembelajaran Matematika di kelas menjadi kegiatan pembelajaran yang efektif dan menyenangkan bagi siswa. Selain motivasi diri guru yang kuat untuk meningkatkan kompetensi profesionalnya, maka perlu didukung oleh peran kepala sekolah dalam tugas supervisi akademik. Pelaksanaan supervisi akademik yang baik oleh kepala sekolah akan menghasilkan kinerja guru dalam memfasilitasi pembelajaran yang baik pula.

Kepala sekolah melaksanakan supervisi akademik dengan menerapkan pendekatan supervisi yang sama untuk semua guru. Pendekatan supervisi yang sama ini tidak efektif untuk meningkatkan kinerja guru dalam melaksanakan kegiatan pembelajaran karena setiap guru memiliki tipe yang berbeda. Hal ini terbukti pada hasil kajian empirik pada hasil penilaian kinerja guru (PKG) di SMP Negeri 1 Merawang, menunjukkan bahwa nilai kinerja guru Matematika dalam kegiatan pembelajaran yang mendidik masih rendah. Rata-rata nilai kinerja guru Matematika dalam kegiatan pembelajaran berdasarkan hasil penilaian kinerja guru tahun 2018, diperoleh data bahwa nilai kinerja kegiatan pembelajaran masih pada kategori cukup yaitu skor rata-rata 69,00.

Berdasarkan hasil observasi pada nilai kinerja guru mata pelajaran Matematika khususnya pada kompetensi kegiatan pembelajaran yang mendidik menunjukkan bahwa faktor yang menyebabkan masih rendahnya nilai kinerja guru dalam kegiatan pembelajaran adalah faktor guru maupun kepala sekolah. Faktor guru mereka memiliki nilai kinerja dalam kegiatan pembelajaran masih rendah dikarenakan guru kurang maksimal melaksanakan sebelas (11) indikator yang menjadi tolok ukur pelaksanaan kegiatan pembelajaran yang mendidik. Secara umum indikator yang tidak maksimal dilaksanakan guru antara lain guru belum melaksanakan aktivitas pembelajaran sesuai dengan rancangan yang telah disusun secara lengkap, guru belum menyesuaikan aktivitas pembelajaran yang dirancang dengan kondisi kelas, guru jarang menggunakan metode pembelajaran yang bervariasi, dan guru kurang memanfaatkan media pembelajaran. Sedangkan dari faktor kepala sekolah, pada saat pelaksanaan supervisi akademik kepala sekolah menggunakan pendekatan supervisi yang sama untuk semua guru tanpa mempertimbangkan tipe guru. Pemilihan pendekatan dan teknik supervisi akademik yang tidak tepat mempengaruhi mutu kinerja guru dalam kegiatan pembelajaran.

Berdasarkan hasil evaluasi tersebut, maka kepala sekolah mengubah pendekatan supervisi yaitu menggunakan pendekatan yang disesuaikan dengan tipe guru. Untuk tipe guru sibuk tetapi memiliki motivasi dan kompetensi yang tinggi maka pendekatan supervisi yang tepat adalah perpaduan pendekatan langsung dan pendekatan tak langsung, tidak menggurui, terjalin kerjasama antara guru dan kepala sekolah, dan pendampingan dalam mempersiapkan kegiatan pembelajaran, serta dilakukan diskusi dan curah pendapat secara terbuka untuk membantu guru meningkatkan kinerjanya dalam melaksanakan kegiatan pembelajaran.

Pendekatan yang mengedepankan kemitraan atau rekan kerja antara kepala sekolah sebagai supervisor dan guru sebagai orang yang disupervisi, lebih bersifat mendampingi melalui diskusi dan curah pendapat secara terbuka dan fleksibel serta memiliki tujuan yang jelas untuk membantu guru berkembang menjadi tenaga-tenaga profesional melalui kegiatan-kegiatan reflektif adalah pendekatan supervisi kolaboratif [2]. Piet A. Sahertian menyatakan bahwa pendekatan supervisi yang menggabungkan pendekatan langsung dan pendekatan tidak langsung adalah pendekatan supervisi kolaboratif [3]. 
Oleh karena itu, penelitian tindakan sekolah (PTS) ini sangat penting dilakukan untuk memperbaiki kinerja guru Matematika dalam kegiatan pembelajaran melalui supervisi akademik kolaboratif. Maka, tujuan PTS ini untuk meningkatkan kinerja guru Matematika dalam pembelajaran melalui supervisi kolaboratif di SMP Negeri 1 Merawang.

Ada beberapa penelitian yang identik dengan PTS ini. Dalam hal ini peneliti mengambil tiga penelitian. Hasil penelitian Dwikurnaningsih [4] menyatakan kualitas pembelajaran yang dilaksanakan guru melalui kegiatan supervisi akademik kolaboratif meningkat yang ditunjukkan dengan keberhasilan pada siklus ke-2 memperoleh skor 90 dengan persentase ketuntasan sebesar $100 \%$. Penelitian kedua yang sejalan dengan penelitian ini juga dilakukan oleh Edi Muntoso [5] dengan judul teknik supervisi edukatif berkelanjutan dalam peningkatan kinerja guru. Penelitian tersebut menunjukkan keberhasilan penerapan supervisi edukatif kolaboratif guna meningkatkan kemampuan guru menyusun perencanaan pembelajaran hingga menerapkannya sehingga meningkatkan kinerja guru. Selain itu, penelitian ketiga yang relevan adalah penelitian yang dilakukan oleh Baiq Sumiati [6] yang berjudul upaya peningkatan kemampuan guru-guru Sekolah Dasar dalam melaksanakan proses pembelajaran menggunakan pendekatan supervisi kolaboratif di sekolah binaan. Hasil penelitian menunjukkan bahwa penerapan pendekatan supervisi kolaboratif dapat meningkatkan kemampuan guru-guru dalam merencanakan, melaksanakan penilaian hasil dan proses pembelajaran, ini dapat dilihat dari hasil analisis keterlaksanaan PBM pada ke 8 subyek penelitian pada siklus I dan siklus II adalah sebagai berikut; 1) untuk administrasi perencanaan pada siklus I baru mencapai nilai rata-rata 70.38 , dan pada siklus II meningkat menjadi 91.38 , 2) untuk penilaian hasil dan proses belajar pada siklus I baru mencapai nilai rata-rata 66.75 , dan pada siklus II meningkat menjadi $87.88,3$ ) untuk pelaksanaan proses pembelajaran pada siklus I mencapai nilai rata-rata 80.25 , dan pada siklus II meningkat menjadi 87.75 .

Tindakan ini untuk meningkatkan kinerja guru Matematika dalam kegiatan pembelajaran. Menurut Muhtar kinerja guru adalah seluruh aktivitas yang dilakukan guru dalam mendidik, mengajar, membimbing, mengarahkan, dan memandu peserta didik [7]. Sedangkan kinerja guru dalam kegiatan pembelajaran sebagaimana yang tertuang dalam Pedoman Pengelolaan Penilaian Kinerja Guru [8] dapat dilakukan guru dengan indikator sebagai berikut: 1) melaksanakan pembelajaran sesuai dengan RPP yang telah disusun secara lengkap; 2) melaksanakan pembelajaran bertujuan untuk membantu proses belajar peserta didik; 3) mengkomunikasikan materi baru sesuai umur dan kemampuan belajar peserta didik; 4) menganggap kesalahan yang dibuat peserta didik sebagai proses pembelajaran; 5) melakukan pembelajaran sesuai isi kurikulum dan berhubungan dengan masalah kehidupan sehari-hari peserta didik; 6) melakukan pembelajaran dengan berbagai variasi metode; 7) mengelola kelas dengan efektif; 8) merancang strategi pembelajaran sesuai dengan kondisi kelas; 9) memberikan kesempatan bagi peserta didik bertanya dan saling interaksi sesama peserta didik; 10) mengatur aktivitas pembelajaran secara sistematis; dan 11) menggunakan berbagai media dalam pembelajaran. Sebagai pengimplementasi indikator kegiatan pembelajaran, guru diharapkan mampu mempertimbangkan situasi dan kondisi yang ada di kelas dan berusaha "memoles" setiap situasi yang muncul menjadi situasi yang memungkinkan berlangsungnya kegiatan pembelajaran[9].

Untuk membantu guru memiliki kinerja baik dalam kegiatan pembelajaran, tugas supervisi akademik yang dilakukan kepala sekolah menjadi sangat penting. Menurut Sahertian pelaksanaan supervisi pada hakikatnya adalah proses pemberian layanan untuk membantu guru memperbaiki kinerjanya dalam kegiatan pembelajaran untuk mencapai tujuan pembelajaran dan meningkatkan mutu hasil belajar [10]. Kepala sekolah melakukan supervisi akademik untuk membimbing dan mengembangkan kemampuan guru dalam menjalankan proses pembelajaran agar tercapai tujuan pembelajaran. Mukhtar dalam Hardono, dkk menyatakan supervisi akademik yaitu kegiatan supervisi melalui pengamatan langsung pada proses pembelajaran yang dilakukan guru di kelas[11]. Oleh karena itu Suhandi Astuti[10] juga menyatakan bahwa supervisi akademik harus dilakukan oleh kepala sekolah secara terus menerus, teratur, dan berkelanjutan. 
Seorang kepala sekolah dalam melaksanakan supervisi akademik hendaknya mengacu pada prinsip supervisi. Prinsip-prinsip supervisi akademik dapat disebutkan sebagai berikut: 1) Praktis, artinya mudah dikerjakan sesuai kondisi sekolah; 2) Sistematis, artinya dikembangkan sesuai dengan program supervisi yang matang dan tujuan pembelajaran; 3) Obyektif, artinya masukan sesuai aspek-aspek instrumen; 4) Realistis, artinya berdasarkan kenyataan yang sebenarnya; 5) Antisipatif, artinya mampu menghadapi masalah-masalah yang mungkin terjadi; 6) Konstruktif, artinya mengembangkan kreativitas dan inovasi guru dalam mengembangkan proses pembelajaran; 7) Kooperatif, artinya ada kerjasama yang baik antara penyelia dan guru dalam mengembangkan pembelajaran; 8) Kekeluargaan, artinya mempertimbangkan silih asah, asih, dan asuh dalam mengembangkan pembelajaran; 9) Demokratis, artinya supervisor tidak boleh mendominasi pelaksanaan supervisi akademik; 10) Aktif, artinya supervisor dan guru harus aktif berpartisipasi; 11) Humanis, artinya mampu menciptakan hubungan kemanusiaan yang harmonis, terbuka, jujur, ajeg, sabar, antusias, dan penuh humor; 12) Berkesinambungan, artinya dilakukan secara teratur dan berkelanjutan oleh kepala sekolah; dan 13) Terpadu, artinya menyatu dengan program pendidikan [12].

Supervisi akademik dapat dilaksanakan dengan berbagai teknik. Menurut Kementerian Pendidikan Nasional[3], teknik supervisi dibagi dua, yaitu teknik individual dan teknik kelompok. Teknik individual apabila kepala sekolah membimbing seorang guru secara individual, berupa kegiatan kunjungan kelas, observasi kelas, pertemuan individual, kunjungan antar kelas, dan menilai diri sendiri. Sedangkan teknik kelompok, apabila dilakukan kepala sekolah untuk membimbing lebih dari satu orang. Kepala sekolah harus memahami kelebihan dan kelemahan setiap teknik supervisi dan sifat atau kepribadian guru, sehingga supervisi akademik yang dilakukan benar-benar dapat membantu guru meningkatkan kinerjanya dalam kegiatan pembelajaan.

Supervisi akademik merupakan sebuah siklus yang dimulai dari perencanaan, pelaksanaan, analisis data hasil supervisi, pemberian umpan balik dan tindak lanjut [13]. Perencanaan yang perlu dilakukan adalah menyusun program supervisi yang memuat tujuan, sasaran, teknik, pendekatan, waktu, biaya dan instrumen supervisi, menyusun sistematika supervisi yang memuat mekanisme pelaksanaan supervisi, pemberian umpan balik, dan tindak lanjut dan pelaporan; serta menyiapkan berbagai instrumen supervisi yang diperlukan. Pada tahap pelaksanaan kepala sekolah mengawali supervisi dengan memeriksa perangkat pembelajaran yang akan digunakan guru mengajar di kelas dengan berpedoman pada instrumen yang telah disepakati bersama. Setelah itu, kepala sekolah dan guru bersepakat menentukan waktu pengamatan proses pembelajaran di kelas. Analisis dilakukan setelah pengamatan selesai. Hasil analisis supervisi akademik dimanfaatkan oleh kepala sekolah untuk memberikan umpan balik (feedback) dan penyusunan rencana tindak lanjut. Setelah kepala sekolah mengamati proses pembelajaran dan melakukan analisis hasil supervisi maka dilanjutkan dengan penyusunan umpan balik. Umpan balik merupakan tanggapan kepala sekolah terhadap proses pembelajaran yang dapat dilakukan secara tertulis ataupun lisan kepada guru yang telah diamati [3]. Umpan balik dijelaskan secara lengkap yang memuat keberhasilan, hal-hal yang harus diperbaiki, saran, alternatif pemecahan masalah/tindak lanjut sehingga guru dapat memahami temuan. Selanjutnya kepala sekolah menyusun program tindak lanjut untuk memperbaiki kegiatan pembelajaran. Tindak lanjut hasil supervisi dengan kegiatan penguatan dan penghargaan kepada guru yang menunjukkan kinerja yang baik; pemberian kesempatan kepada guru untuk mengikuti program pengembangan keprofesionalan berkelanjutan, seperti pelatihan, Worskshop, In House Training di sekolah, dan pemodelan oleh guru kolega. Pemberian tindak lanjut disesuaikan dengan temuan hasil supervisi.

Pada era modern ini kepala sekolah dapat melaksanakan supervisi akademik yang lebih mengutamakan kenyamanan bagi guru yang disupervisi. Hakikatnya supervisi akademik bukan penilaian kinerja sehingga pendekatan supervisi yang diterapkan dapat sebagai upaya mengeratkan kerjasama antara kepala sekolah dan guru. Pendekatan supervisi kolaboratif merupakan salah satu pendekatan supervisi yang dapat digunakan oleh kepala sekolah. 
Pendekatan kolaboratif, yaitu pendekatan supervisi yang dilakukan oleh sesama guru. Pendekatan kolaboratif ini menekankan prinsip bahwa sesama guru bertanggung jawab terhadap pertumbuhan profesional mereka, belajar kooperatif dan secara kolega, serta saling bekerja sama[14]. Sedangkan Nollan menyatakan pendekatan supervisi kolaboratif adalah pendekatan yang memadukan pendekatan langsung dan tak langsung [12]. Pendekatan supervisi kolaboratif menjadi pendekatan baru.

Keunggulan pendekatan kolaboratif adalah 1) selama supervisi berlangsung terjadi komunikasi dua arah yakni dari kepala sekolah ke guru dan sebaliknya; 2) memberikan solusi terhadap masalah yang dihadapi guru dengan cepat, karena pendekatan dimulai dengan memunculkan hubungan baik antara keduanya; 3) pada pelaksanaannya kepala sekolah dan guru bersama-sama untuk menetapkan perencanaan, proses supervisi dan diskusi membahas masalah yang dihadapi guru; 4) menempatkan kepala sekolah sebagai rekan kerja bagi guru dalam pembimbingan, antara mereka berbagi keahlian, diskusi menentukan tujuan dan sasaran, menyusun instrumen, membantu guru meningkatkan kinerja melalui kegiatankegiatan reflektif dan komunikasi hasil supervisi dilaksanakan secara terbuka dan fleksibel [4].

Pendekatan supervisi kolaboratif dilaksanakan sebagai upaya mengefektifkan proses supervisi. Jika kepala sekolah memahami guru yang disupervisi maka diperoleh hasil supervisi yang memuaskan sebagaimana yang diharapkan.

Langkah-langkah pendekatan supervisi kolaboratif sebagai berikut: 1) pra-observasi, kepala sekolah bersama guru melakukan diskusi tentang fokus masalah guru dalam melaksanakan kinerjanya dalam kegiatan pembelajaran dan menentukan waktu pengamatan; 2) observasi, kepala sekolah melaksanakan pengamatan bersama guru lain saat guru melaksanakan kegiatan pembelajaran; 3) pasca-observasi, kepala sekolah bersama guru melaksanakan refleksi pelaksanaan pembelajaran [2].

\section{Metode Penelitian}

\subsection{Tempat dan Waktu Penelitian}

Penelitian dilaksanakan di SMP Negeri 1 Merawang Kabupaten Bangka dengan karakteristik di sekolah ini kepala sekolah selalu melakukan supervisi akademik secara langsung, padahal tipe guru di sekolah ini memiliki motivasi untuk selalu merefleksi kinerjanya dan berbagi pengalaman dengan rekan sejawatnya.

Kegiatan supervisi dilaksanakan dalam dua siklus. Siklus I dilaksanakan 4 Februari 2019 sampai dengan 28 Maret 2019 dan Siklus II 1 April 2019 sampai dengan 29 Juni 2019.

\subsection{Subjek Penelitian}

Subjek penelitian adalah Guru Matematika SMP Negeri 1 Merawang berjumlah 3 orang terdiri atas 1 orang GTT dan 2 orang PNS. Ketiga guru Matematika merupakan tipe guru yang aktif dalam berbagai kegiatan di sekolah sehingga kurang fokus dalam kegiatan pembelajaran. Selain itu guru Matematika memiliki motivasi untuk selalu merefleksi kinerjanya dan berbagi pengalaman dengan rekan sejawatnya.

\subsection{Rancangan Penelitian}

Penelitian ini merupakan penelitian tindakan dengan model Kemmis dan Mc. Taggart. Dalam model ini, alur penelitian terdiri dari empat kegiatan pokok, yaitu perencanaan, tindakan, pengamatan, dan refleksi. Menurut Arikunto, model penelitian tindakan ini berbentuk spiral [15]. Pelaksanaannya selama dua siklus. Masing-masing siklus terdapat dua pertemuan.

Perencanaan diawali dengan pengumpulan data awal berupa data penilaian kinerja guru tahun 2018 pada kompetensi profesional yang keempat yaitu kegiatan pembelajaran yang mendidik. Selanjutnya pertemuan dengan guru Matematika membahas masalah pembelajaran dan langkah-langkah pemecahan masalah dari hasil penilaian kinerja guru tahun 2018 khususnya kompetensi kegiatan pembelajaran yang mendidik. Kepala sekolah dan guru menyusun program supervisi. Kepala sekolah menyusun instrumen penelitian, meliputi: lembar 
observasi pelaksanaan supervisi kolaboratif, lembar observasi kinerja guru dalam kegiatan pembelajaran, dan dokumentasi.

Tindakan dilakukan dengan langkah-langkah supervisi kolaboratif sebanyak 2 (dua) pertemuan pada tiap siklus. Kesatu, tahap pra-observasi, kepala sekolah bersama 3 orang guru Matematika melakukan diskusi tentang fokus masalah guru dalam kegiatan pembelajaran, memberikan kesempatan kepada guru menjelaskan perencanaan pembelajaran yang akan diamati, menjelaskan tujuan pengamatan, dan menentukan waktu pengamatan; kedua, tahap observasi pembelajaran, kepala sekolah melaksanakan supervisi kolaboratif bersama dengan tiga orang guru Matematika pada saat guru sedang melaksanakan kegiatan pembelajaran sesuai dengan kesepakatan jadwal yang dilakukan sesuai dengan prinsip supervisi kolaboratif; ketiga, tahap pasca-observasi, kepala sekolah bersama tiga orang guru Matematika melaksanakan refleksi pelaksanaan pembelajaran, menyiapkan guru untuk menetapkan fokus dalam pertemuan pra-observasi berikutnya, menyetujui rencana dan pertemuan tindak lanjut; keempat, kepala sekolah bersama guru menganalisis temuan-temuan pada pelaksanaan pengamatan, mendiskusikan hasil analisis dan menyimpulkan; kelima, menyusun rencana pemberian umpan balik dan melakukan pemberian umpan balik kepada guru; keenam, kepala sekolah merencanakan program tindak lanjut dan pemberian tindak lanjut.

Pengamatan, pada prinsipnya pengamatan dilaksanakan selama penelitian berlangsung. Sasaran utama pengamatan adalah untuk melihat proses pelaksanaan supervisi kolaboratif dan kinerja guru Matematika dalam kegiatan pembelajaran. Pengamatan dilakukan oleh wakil kepala sekolah bidang kurikulum dengan menggunakan pedoman instrumen observasi keterlaksanaan supervisi.

Refleksi merupakan tahap penentu. Seluruh kegiatan dianalisis. Hasil analisis dimanfaatkan kepala sekolah dan guru sebagai bahan untuk perbaikan siklus berikutnya terkait proses supervisi kolaboratif dan kinerja guru dalam pembelajaran.

\subsection{Teknik Pengumpulan data}

Teknik pengumpulan data pada penelitian ini adalah observasi dan dokumentasi. Observasi merupakan proses mengamati dan mencatat secara sistematis terhadap gejala-gejala yang nampak dalam penelitian[16]. Sedangkan pendapat lain menyatakan observasi merupakan teknik pengumpulan data dengan cara mengamati secara langsung maupun tidak langsung[17]. Jadi dapat disimpulkan bahwa observasi adalah teknik pengumpulan data dengan melakukan pengamatan dan pencatatan secara langsung maupun tidak langsung terhadap gejala yang tampak dalam objek penelitian.

Dalam penelitian ini teknik observasi digunakan untuk mengamati dan mencatat data pelaksanaan supervisi kolaboratif dan data kinerja guru dalam kegiatan pembelajaran. Instrumen observasi yang digunakan berupa pedoman observasi kinerja guru dalam kegiatan pembelajaran dan pedoman observasi pelaksanaan supervisi kolaboratif. Dokumentasi digunakan untuk mendapatkan data pelaksanaan supervisi kolaboratif baik itu foto maupun dokumen seperti program supervisi, RPP, dan catatan lapangan oleh pengamat.

\subsection{Teknik Analisis Data}

Data dianalisis secara kualitatif dan kuantitatif. Analisis kualitatif digunakan untuk menjelaskan keseluruhan data yang terkumpul, baik data kuantitatif maupun data kualitatif, yaitu hasil dokumentasi pada saat melaksanakan supervisi kolaboratif. Adapun analisis kuantitatif digunakan untuk mengetahui peningkatan kinerja guru dalam kegiatan pembelajaran berdasarkan IPKG yang telah ditetapkan oleh Peraturan Menteri Negara Pendayagunaan Aparatur Negara dan Reformasi Birokrasi Nomor 16 Tahun 2009, yaitu Nilai $86<A \leq 100=$ sangat baik (A) berhasil; Nilai $70<\mathrm{B} \leq 85=$ baik (B) berhasil; Nilai $55<\mathrm{C} \leq 69=$ cukup (C) belum berhasil; dan Nilai $\leq 55$ = kurang (D) belum berhasil.

\subsection{Indikator keberhasilan}

Indikator keberhasilan yang dicapai oleh peneliti dalam penelitian ini ialah peningkatan kinerja guru dalam kegiatan pembelajaran. Siklus dihentikan jika nilai kinerja guru dalam 
kegiatan pembelajaran sudah mencapai baik dengan nilai 70-85. Aspek-aspek kinerja guru yang ditujukan sebagai indikator keberhasilan, yaitu: 1) melaksanakan pembelajaran sesuai dengan RPP; 2) melaksanakan pembelajaran bertujuan untuk membantu proses belajar peserta didik; 3) mengkomunikasikan materi baru sesuai umur dan kemampuan belajar peserta didik; 4) menganggap kesalahan peserta didik sebagai proses pembelajaran; 5) melakukan pembelajaran sesuai isi kurikulum dan berhubungan dengan masalah kehidupan sehari-hari peserta didik; 6) melakukan pembelajaran dengan berbagai variasi metode; 7) mengelola kelas dengan efektif; 8) merancang strategi pembelajaran sesuai dengan kondisi kelas; 9) memberikan kesempatan bagi peserta didik aktif dalam pembelajaran; 10) mengatur aktivitas pembelajaran secara sistematis sesuai materi; 11) menggunakan berbagai media dalam pembelajaran

\section{Hasil dan Pembahasan}

\subsection{Deskripsi Hasil Tindakan}

Pelaksanaan supervisi kolaboratif pada PTS ini dilakukan sesuai rancangan, yakni empat tahap setiap siklusnya. Pada kedua siklus penelitian, mulai perencanaan hingga refleksi tidak ada perbedaan yang prinsip. Tahapan PTS dan langkah-langkah supervisi kolaboratif telah diuraikan secara rinci pada bagian metode penelitian. Pada bagian ini dideskripsikan hasil tindakan pada kedua siklus.

Kinerja guru Matematika dalam kegiatan pembelajaran diamati dan diukur menggunakan lembar observasi kinerja guru dalam kegiatan pembelajaran. Hasil pengamatan terhadap kinerja guru Matematika dalam kegiatan pembelajaran di SMP Negeri 1 Merawang yang diukur dan diamati terhadap tiga guru dapat dilihat pada tabel 1 berikut ini.

Tabel 1. Kinerja guru dalam kegiatan pembelajaran siklus I

\begin{tabular}{|c|l|c|c|c|}
\hline \multirow{2}{*}{ No. } & \multicolumn{1}{|c|}{ Indikator } & \multicolumn{3}{|c|}{ Skor rata-rata } \\
\cline { 3 - 5 } & & M1 & M2 & M3 \\
\hline 1 & Melaksanakan pembelajaran sesuai dengan RPP & 2,5 & 3 & 2,5 \\
\hline 2 & $\begin{array}{l}\text { Melaksanakan pembelajaran bertujuan untuk membantu } \\
\text { proses belajar peserta didik }\end{array}$ & 1,5 & 1,5 & 1 \\
\hline 3 & $\begin{array}{l}\text { Mengkomunikasikan materi baru sesuai umur dan kemampuan } \\
\text { belajar peserta didik }\end{array}$ & 3 & 2,5 & 3 \\
\hline 4 & $\begin{array}{l}\text { Menganggap kesalahan yang dibuat peserta didik sebagai } \\
\text { proses pembelajaran }\end{array}$ & 2,5 & 2,5 & 2,5 \\
\hline 5 & $\begin{array}{l}\text { Melakukan pembelajaran sesuai isi kurikulum dan } \\
\text { berhubungan dengan masalah kehidupan sehari-hari peserta } \\
\text { didik }\end{array}$ & 2,5 & 2,5 & 2,5 \\
\hline 6 & Melakukan pembelajaran dengan berbagai variasi metode & 2 & 1,5 & 2 \\
\hline 7 & Mengelola kelas dengan efektif & 3 & 1 & 1 \\
\hline 8 & Merancang strategi pembelajaran sesuai dengan kondisi kelas & 2 & 2 & 2 \\
\hline 9 & $\begin{array}{l}\text { Memberikan kesempatan bagi peserta didik untuk bertanya } \\
\text { dan saling interaksi sesama peserta didik }\end{array}$ & 2 & 3 & 2 \\
\hline 10 & Mengatur aktivitas pembelajaran secara sistematis & 1,5 & 1,5 & 1,5 \\
\hline 11 & Pemanfaatan media dan sumber belajar & 2 & 2 & 2 \\
\hline & Jumlah skor & 24,5 & 23 & 22 \\
\hline & Keberhasilan & 74,24 & 69,70 & 66,67 \\
\hline & Kriteria & B & B & C \\
\hline
\end{tabular}

Berdasarkan data hasil observasi pada tabel 1 di atas, maka kepala sekolah dan guru melakukan refleksi pasca-observasi sehingga ditemukan masalah kinerja guru dalam kegiatan 
pembelajaran. Fokus masalah guru yang ditemukan pada siklus I dapat dilihat pada tabel 2 berikut ini.

Tabel 2. Fokus masalah kinerja guru pada siklus I

\begin{tabular}{|c|l|l|}
\hline No. & \multicolumn{1}{|c|}{ Kode Guru } & \multicolumn{1}{|c|}{$\begin{array}{c}\text { Fokus masalah pada } \\
\text { indikator }\end{array}$} \\
\hline 1 & M1 & $2,6,8,9,10,11$ \\
\hline 2 & M2 & $2,6,7,8,10,11$ \\
\hline 3 & M3 & $2,6,7,8,9,10,11$ \\
\hline
\end{tabular}

Selanjutnya fokus masalah yang ditemukan dianalisis. Dari hasil analisis maka kepala sekolah dan guru menyepakati pemberian umpan balik dan tindak lanjut. Kepala sekolah memberikan umpan balik secara lisan dan penguatan pada guru yang belum berhasil. Sedangkan guru yang sudah berhasil diberikan penghargaan. Selanjutnya tindak lanjut dilakukan dengan cara pemberian pemodelan pembelajaran bagi guru. Pemodelan pembelajaran dilakukan oleh wakil kepala sekolah bidang kurikulum. Ketiga orang guru Matematika mengamati pemodelan pembelajaran.

Berdasarkan hasil pengamatan keterlaksanaan supervisi kolaboratif secara umum pada siklus I, rata-rata skor pelaksanaan supervisi siklus I pertemuan kesatu sebesar 77,78 kriteria baik dan pertemuan kedua sebesar 83,33 kriteria baik. Hasil pengamatan pelaksanaan supervisi akademik kolaboratif yang dilakukan kepala sekolah pada siklus I dapat dilihat pada tabel 3 berikut ini.

Tabel 3 Data hasil observasi pelaksanaan supervisi Siklus I

\begin{tabular}{|c|l|c|c|}
\hline \multirow{2}{*}{ No. } & \multirow{2}{*}{ Indikator } & \multicolumn{2}{c|}{ Siklus I } \\
\cline { 3 - 4 } & & Pert 1 & Pert 2 \\
\hline 1 & Melaksanakan pra-supervisi kolaboratif & 3 & 3 \\
\hline 2 & Melaksanakan supervisi kolaboratif & 2 & 2 \\
\hline 3 & Melaksanakan pasca-supervisi kolaboratif & 3 & 3 \\
\hline 4 & Melaksanakan analisis data hasil supervisi & 3 & 3 \\
\hline 5 & Melaksanakan pemberian umpan balik & 2 & 2 \\
\hline 6 & Melaksanakan pemberian tindak lanjut & 1 & 2 \\
\hline & Jumlah skor & 14 & 15 \\
\hline & Nilai & 77,78 & 83,33 \\
\hline & Kriteria & Baik & Baik \\
\hline
\end{tabular}

Refleksi hasil observasi adalah pelaksanaan supervisi akademik kolaboratif walaupun sudah baik tetapi belum terlaksana sepenuhnya. Hal ini dikarenakan ada 3 (tiga) indikator yang belum terlaksana secara lengkap, yaitu: 1) pada indikator melaksanakan observasi, kepala sekolah belum membuat catatan-catatan pelengkap pada instrumen observasi pembelajaran; 2) kepala sekolah memberikan umpan balik secara lisan dan penguatan pada guru yang belum berhasil. Sedangkan guru yang sudah berhasil belum diberikan penghargaan; 3) pada pelaksanaan tindak lanjut, kepala sekolah belum menugaskan guru mengikuti pelatihan, dan Worskshop, IHT atau seminar.

Berdasarkan hasil refleksi sikulus I. maka perlu dilaksanakan perbaikan pelaksanaan supervisi pada siklus II. Adapun perbaikan kegiatan kepala sekolah untuk siklus II berdasarkan refleksi yang dilakukan pada siklus I, yaitu: 1) Pada perencanaan siklus II, kepala sekolah dan guru kembali memeriksa dan menentukan fokus masalah yang ditemukan pada siklus I; 2) Pada tahapan pra-observasi kepala sekolah dan guru curah pendapat mengenai penerapan model pembelajaran yang digunakan; mengelola kelas; merancang strategi pembelajaran yang efektif sesuai dengan kondisi kelas; mengubah media pembelajaran yang menarik perhatian peserta 
didik; 3) Pada tahapan observasi kepala sekolah mengamati pembelajaran secara lengkap dan teliti dengan menggunakan instrumen pengamatan dan membuat catatan penting agar dapat mendukung analisis data; 4) Pada tahapan pasca-observasi, kepala sekolah dan guru melakukan refleksi diri setelah pembelajaran.

Siklus II dilaksanakan berdasarkan temuan siklus I. Tahapan yang sudah baik dipertahankan, sedangkan tahapan yang keberhasilannya kecil diperbaiki pada siklus II ini. Berikut ini hasil pengamatan kinerja guru dalam kegiatan pembelajaran pada siklus II diperoleh data yang tersaji pada tabel 4 berikut.

Tabel 4. Kinerja guru dalam kegiatan pembelajaran siklus II

\begin{tabular}{|c|l|c|c|c|}
\hline \multirow{2}{*}{ No. Indikator } & \multicolumn{3}{|c|}{ Skor rata-rata } \\
\cline { 3 - 5 } & & M1 & M2 & M3 \\
\hline 1 & Melaksanakan pembelajaran sesuai dengan RPP & 3 & 3 & 3 \\
\hline 2 & $\begin{array}{l}\text { Melaksanakan pembelajaran bertujuan untuk membantu } \\
\text { proses belajar peserta didik }\end{array}$ & 3 & 2,5 & 2,5 \\
\hline 3 & $\begin{array}{l}\text { Mengkomunikasikan materi baru sesuai umur dan } \\
\text { kemampuan belajar peserta didik }\end{array}$ & 3 & 2,5 & 3 \\
\hline 4 & $\begin{array}{l}\text { Menganggap kesalahan yang dibuat peserta didik sebagai } \\
\text { proses pembelajaran }\end{array}$ & 3 & 2,5 & 2,5 \\
\hline 5 & $\begin{array}{l}\text { Melakukan pembelajaran sesuai isi kurikulum dan } \\
\text { berhubungan dengan masalah kehidupan sehari-hari } \\
\text { peserta didik }\end{array}$ & 3 & 3 & 3 \\
\hline 6 & Melakukan pembelajaran dengan berbagai variasi metode & 2,5 & 2,5 & 2,5 \\
\hline 7 & Mengelola kelas dengan efektif & 3 & 2,5 & 3 \\
\hline 8 & $\begin{array}{l}\text { Merancang strategi pembelajaran sesuai dengan kondisi } \\
\text { kelas }\end{array}$ & 2,5 & 2 & 2,5 \\
\hline 9 & $\begin{array}{l}\text { Memberikan kesempatan bagi peserta didik untuk bertanya } \\
\text { dan saling interaksi sesama peserta didik }\end{array}$ & 2,5 & 3 & 2,5 \\
\hline 10 & Mengatur aktivitas pembelajaran secara sistematis & 1,5 & 2 & 2 \\
\hline 11 & Pemanfaatan media dan sumber belajar & 2,5 & 2,5 & 3 \\
\hline & Jumlah skor & 29,50 & 28,00 & 29,50 \\
\hline & Keberhasilan & 89,39 & 84,85 & 89,39 \\
\hline & Kriteria & B & B & B \\
\hline
\end{tabular}

Berdasarkan tabel 4 di atas, dapat diketahui bahwa rata-rata keberhasilan yang diperoleh semua guru sebesar 87,88 dengan kriteria B (baik). Pada tindakan siklus II ini, terdapat peningkatan kinerja guru dalam kegiatan pembelajaran dari pelaksanaan tindakan siklus I lalu. Tahap akhir penelitian dilakukan refleksi tehadap pelaksanaan supervisi kolaboratif dan kinerja guru Matematika dalam pembelajaran.

Hasil refleksi pasca-observasi diketahui bahwa fokus masalah guru berkurang, yaitu: 1) Guru M1 berhasil meningkatkan keberhasilan fokus masalah dari enam indikator berkurang menjadi satu indikator yaitu indikator mengatur aktivitas pembelajaran secara sistematis; 2) Guru M2 berhasil meningkatkan keberhasilan fokus masalah dari enam indikator berkurang menjadi dua indikator; 3) Guru M3 berhasil meningkatkan keberhasilan fokus masalah dari tujuh indikator berkurang menjadi satu indikator.

Sedangkan rata-rata skor keterlaksanaan supervisi oleh kepala sekolah pada siklus II pertemuan kesatu sebesar 94,44 kriteria sangat baik dan pertemuan kedua sebesar 100,00 kriteria sangat baik. Namun demikian masih ada 1 (satu) indikator yang belum terlaksana secara lengkap, yaitu melaksanakan tindak lanjut. Kepala sekolah belum menugaskan guru mengikuti 
pelatihan, dan Worskshop, IHT atau seminar. keterlaksanaan supervisi akademik kolaboratif pada siklus II dapat dilihat pada tabel 5 berikut ini.

Tabel 5 Data hasil observasi pelaksanaan supervisi Siklus II

\begin{tabular}{|c|l|c|c|}
\hline \multirow{2}{*}{ No. } & \multirow{2}{*}{ Indikator } & \multicolumn{2}{|c|}{ Siklus II } \\
\cline { 3 - 4 } & & Pert 1 & Pert 2 \\
\hline 1 & Melaksanakan pra-supervisi kolaboratif & 3 & 3 \\
\hline 2 & Melaksanakan supervisi kolaboratif & 3 & 3 \\
\hline 3 & Melaksanakan pasca-supervisi kolaboratif & 3 & 3 \\
\hline 4 & Melaksanakan analisis data hasil supervisi & 3 & 3 \\
\hline 5 & Melaksanakan pemberian umpan balik & 3 & 3 \\
\hline 6 & Melaksanakan pemberian tindak lanjut & 2 & 3 \\
\hline & Jumlah skor & 17 & 18 \\
\hline & Nilai & 94,44 & 100,00 \\
\hline & Kriteria & $\begin{array}{c}\text { Sangat } \\
\text { baik }\end{array}$ & $\begin{array}{c}\text { Sangat } \\
\text { baik }\end{array}$ \\
\hline
\end{tabular}

Hasil refleksi keterlaksanaan supervisi sebagai berikut: 1) Kepala sekolah telah menyusun perencanaan kembali kegiatan supervisi sesuai dengan temuan pada siklus I; 2) Guru merasa nyaman ketika diskusi pra-observasi, Guru diberi kesempatan menjelaskan kesiapan proses pembelajaran dan memberikan penjelasan tentang langkah-langkah yang akan diambil guru bila kondisi kelas tidak sesuai dengan yang diharapkan guru; 3) Kepala sekolah dan guru kolaborator mengamati guru yang sedang mengajar dengan catatan-catatan khusus tentang kejadian positif dan negatif pada pembelajaran tersebut; 4) Kepala sekolah dan guru mendiskusikan kelebihan dan kekurangan pembelajaran pasca pengamatan pembelajaran; 5) Indikator yang kurang langsung dicarikan solusinya pada saat pemberian tindak lanjut.

Berdasarkan hasil refleksi siklus II maka disimpulkan bahwa tindakan yang dikenakan sudah berhasil dan oleh sebab itu tidak perlu lagi tindakan siklus selanjutnya.

\subsection{Pembahasan}

Pelaksanaan supervisi dengan pendekatan kolaboratif dilakukan pada tipe guru yang terlalu sibuk/kurang memusatkan perhatian (unfocus worker). Pendekatan kolaboratif adalah cara pendekatan yang memadukan cara pendekatan direktif dan non-direktif menjadi cara pendekatan baru [3]. Pada pendekatan ini supervisor maupun guru bersama-sama, bersepakat untuk menetapkan struktur, proses dan kriteria dalam melaksanakan proses percakapan terhadap masalah yang dihadapi guru. Cara pendekatan kolaboratif sengaja dipilih oleh kepala sekolah untuk mensupervisi guru Matematika dengan alasan yaitu tiga orang guru Matematika di SMP Negeri 1 Merawang adalah guru sibuk sehingga kurang memusatkan perhatian pada kinerjanya sedangkan ketiganya memiliki motivasi dan kompetensi baik.

Dari hasil pelaksanaan supervisi kolaboratif pada siklus pertama dan kedua mengisyaratkan bahwa pendekatan kolaboratif dapat meningkatkan kinerja guru Matematika dalam kegiatan pembelajaran. Hal ini karena pendekatan kolaboratif merupakan supervisi yang tidak menggurui, terjalin kerjasama antara guru dan kepala sekolah, dan pendampingan dalam mempersiapkan kegiatan pembelajaran, serta dilakukan diskusi dan curah pendapat secara terbuka untuk membantu guru meningkatkan kinerjanya dalam melaksanakan kegiatan pembelajaran. Melalui supervisi kolaboratif, masalah-masalah pembelajaran akan bisa dipecahkan secara bersama-sama antara kepala sekolah dan guru yang dilaksanakan bersuasana kekeluargaan. 
Dalam melaksanakan supervisi akademik kolaboratif terhadap peningkatan kinerja guru Matematika di SMP Negeri 1 Merawang, kepala sekolah telah melalui tiga langkah, yaitu: (1) curah pendapat pada pra-observasi, (2) melaksanakan observasi, (3) melakukan refleksi pada pasca-observasi, dan diikuti (4) melakukan analisis, (5) memberikan umpan balik, dan (6) memberikan tindak lanjut.

Hasil pengamatan keterlaksanaan supervisi pada siklus I dan siklus II ada peningkatan. Jumlah skor pada akhir siklus I yaitu 83,33 dengan kriteria baik, sedangkan pada akhir siklus II jumlah skor yang diperoleh adalah 100,00 dengan kriteria sangat baik. Peningkatan keterlaksanaan supervisi kolaboratif pada siklus I dan siklus II dapat dilihat pada tabel 6 berikut ini.

Tabel 6 Rekapitulasi pelaksanaan supervisi kolaboratif

\begin{tabular}{|c|l|c|c|c|c|}
\hline \multirow{2}{*}{ No. } & \multirow{2}{*}{ Indikator } & \multicolumn{2}{c|}{ Siklus I } & \multicolumn{2}{c|}{ Siklus II } \\
\cline { 3 - 6 } & & Pert 1 & Pert 2 & Pert 1 & Pert 2 \\
\hline 1 & Jumlah skor & 14 & 15 & 17 & 18 \\
\hline 2 & Nilai & 77,78 & 83,33 & 94,44 & 100,00 \\
\hline & Kriteria & Baik & Baik & $\begin{array}{c}\text { Sangat } \\
\text { baik }\end{array}$ & $\begin{array}{c}\text { Sangat } \\
\text { baik }\end{array}$ \\
\hline
\end{tabular}

Jika peningkatan keterlaksanaan supervisi kolaboratif pada siklus I dan siklus II disajikan dengan diagram maka hasilnya adalah seperti gambar 1 berikut.

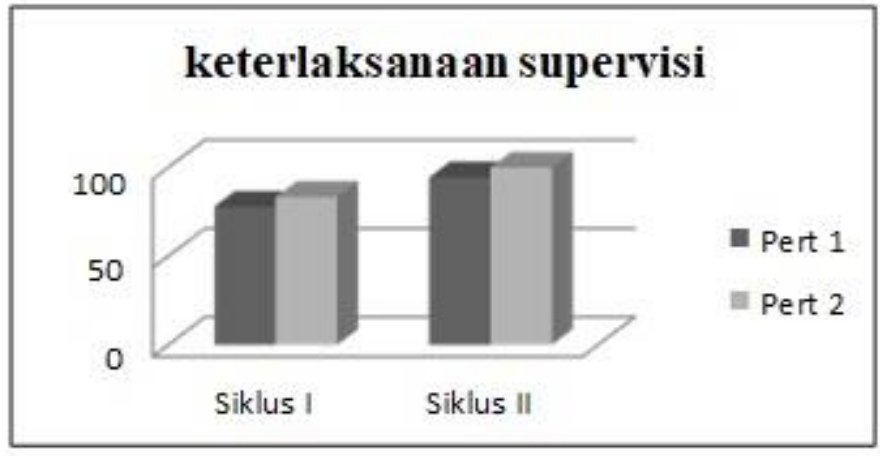

Gambar 1. Grafik keterlaksanaan supervisi kolaboratif Pada Siklus I dan Siklus II

Setelah kepala sekolah melaksanakan supervisi kolaboratif menunjukkan adanya peningkatan kinerja guru dalam kegiatan pembelajaran. Pada penelitian siklus I skor rata-rata belum mencapai kriteria keberhasilan karena baru mencapai skor 70,71. Untuk itu penelitian dilanjutkan ke siklus II dengan melihat catatan-catatan penting yang masih perlu direfleksikan lagi untuk supervisi berikutnya. Pelaksanaan tindakan siklus II ini merupakan tindak lanjut dari siklus I. Pada siklus I ditemukan faktor penyebab kurang tercapainya indikator keberhasilan diantaranya pada siklus I yaitu pembelajaran yang dilaksanakan oleh guru belum sepenuhnya membantu proses belajar peserta didik, guru belum dapat mengelola kelas dengan efektif, guru sudah menggunakan model dan metode pembelajaran yang menarik tetapi belum sepenuhnya melaksanakan sintaks pembelajaran sesuai dengan model pembelajaran, guru belum dapat menumbuhkan partisipasi aktif peserta didik dan menumbuhkan keceriaan dan antusiasme peserta didik, guru baru melakukan aktivitas pembelajaran sesuai dengan materi tetapi belum menumbuhkan kreativitas dan kemandirian sesuai bakat, minat peserta didik, dan guru telah menggunakan media pembelajaran dan melibatkan peserta didik memanfaatkan media tetapi media yang digunakan belum menarik. 
Tindakan yang dilakukan pada siklus II masih tetap menggunakan pendekatan kolaboratif tetapi dengan berbagai perbaikan tindakan sesuai dengan hasil refleksi pada siklus I. Kinerja guru Matematika dalam kegiatan pembelajaran meningkat jika dibandingkan dengan siklus I. Hal ini dapat dilihat pada tabel 7 di bawah ini.

Tabel 7. Perbandingan kinerja guru pada Siklus I dan Siklus II

\begin{tabular}{|c|c|c|c|}
\hline No. & Hasil supervisi & $\begin{array}{c}\text { Rata-rata } \\
\text { Siklus I }\end{array}$ & $\begin{array}{c}\text { Rata-rata } \\
\text { Siklus II }\end{array}$ \\
\hline 1 & Keberhasilan & $\mathbf{7 0 , 3 3}$ & $\mathbf{8 7 , 6 7}$ \\
\hline 2 & Kriteria & $\mathbf{B}$ & $\mathbf{B}$ \\
\hline
\end{tabular}

Jika rata-rata kinerja yang dicapai guru pada siklus I dan siklus II disajikan dengan diagram maka hasilnya adalah seperti gambar 2 berikut.

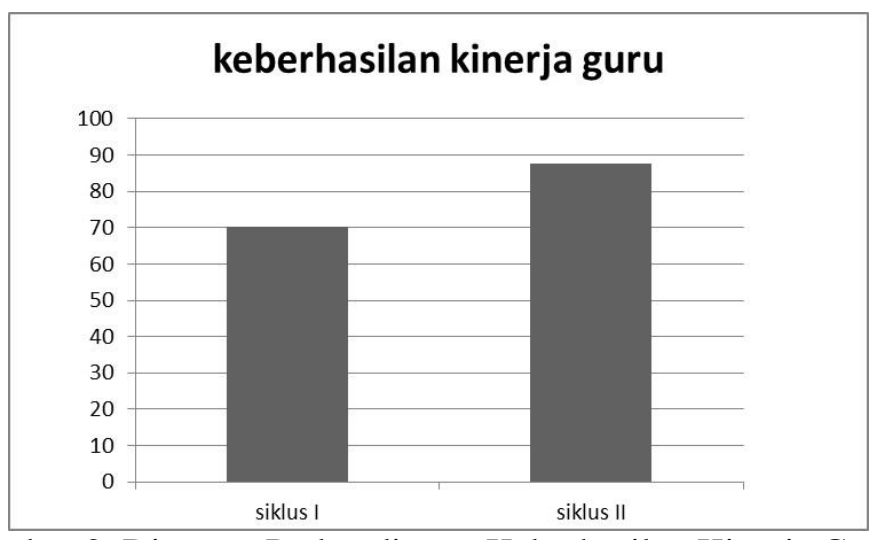

Gambar 2. Diagram Perbandingan Keberhasilan Kinerja Guru

Pada Siklus I dan Siklus II

Berdasarkan diagram pada gambar 2 di atas, keberhasilan kinerja guru mengalami peningkatan pada setiap tahapan penelitian. Pada tahap siklus I rata-rata keberhasilan guru mencapai skor 70,71 dan pada siklus II skor meningkat menjadi 80,81. Pada tindakan siklus II kinerja guru di atas artinya sudah mencapai kriteria keberhasilan yang ditetapkan peneliti yaitu 70-85 sehingga penelitian dihentikan.

Dengan demikian kedua variabel penelitian tindakan ini sudah mencapai kriteria keberhasilan yang telah ditetapkan. Hipotesis yang diajukan terbukti, bahwa terjadi peningkatan kinerja guru Matematika dalam pembelajaran melalui supervisi akademik kolaboratif.

\section{Kesimpulan}

Berdasarkan hasil analisis data dan pembahasan hasil penelitian yang dilakukan dalam penelitian tindakan berkaitan dengan kegiatan supervisi akademik kolaboratif terhadap kinerja guru dalam kegiatan pembelajaran pada SMP Negeri 1 Merawang tahun pelajaran 2018/2019, dapat ditarik simpulan bahwa terjadi peningkatan kinerja guru Matematika dalam kegiatan pembelajaran melalui supervisi akademik kolaboratif.

Berdasarkan temuan-temuan penelitian tindakan ini, ada beberapa saran yang perlu disampaikan kepada pengambil kebijakan sekolah, di antaranya adalah supervisi terhadap semua guru perlu dilakukan secara periodik dan ditetapkan pada awal tahun pelajaran (pada saat pembagian tugas), supervisi akademik ternyata dapat meningkatkan kinerja guru dan hasil belajar siswa jika dilaksanakan secara kolaboratif, supervisi akademik kolaboratif akan bermakna jika penelitinya bersifat terbuka, bermitra, dan tidak menggurui, supervisi akademik 
kolaboratif dapat diterapkan bagi guru yang memiliki tingkat kesibukan yang tinggi, dan perlu memberi kesempatan pada guru-guru yang dianggap sudah mampu mensupervisi guru lain.

\section{Daftar Pustaka}

[1] Departemen Pendidikan Nasional. Undang-Undang Nomor 14 Tahun 2005 tentang Guru dan Dosen pasal 1 ayat 1. Jakarta. 2005.

[2] Simbolon, Marike. Penerapan Pendekatan Supervisi Kolaboratif Untuk Meningkatkan Kompetensi Profesional Guru di SD Negeri 10 Lumban Suhisuhi Kecamatan Pangururan Kabupaten Samosir. Majalah Ilmiah INTI. 2018. Volume 6, Nomor 1: 115.

[3] Karwati, Wawat. Supervisi Akademik Untuk Meningkatkan Kompetensi Guru SDN Santaka Kecamatan Cimanggung Dalam Melaksanakan Standar Proses. Jurnal Pedagogik Pendidikan Dasar. 2019; Jilid 6, Nomor 1: 49.

[4] Dwikurnaningsih, Yari. Supervisi Akademik Melalui Pendekatan Kolaboratif oleh Kepala Sekolah dalam Meningkatkan Kualitas Pembelajaran Di SD. Jurnal Satya Wijaya. 2018; Vol. XXXIV No. 2, Desember: 104.

[5] Muntoso, Edi. Teknik Supervisi Edukatif Berkelanjutan Dalam Peningkatan Kinerja Guru. Jurnal Penelitian Tindakan Sekolah dan Kepengawasan. 2019; Vol. I No. 2: 1.

[6] Sumiati. Baiq. Upaya Peningkatan Kemampuan Guru-Guru Sekolah Dasar Dalam Melaksanakan Proses Pembelajaran Menggunakan Pendekatan Supervisi Kolaboratif Di Sekolah Binaan. GaneC Swara. 2017; Vol. 11 No.1: 102.

[7] Abas, Erjati. Magnet kepemimpinan kepala madrasah terhadap kinerja guru. Jakarta: PT. Elex Media Komputindo. 2017: 24.

[8] Direktorat Jenderal Guru dan Tenaga Kependidikan. Pedoman Pengelolaan Penilaian Kinerja Guru. Jakarta: Kementerian Pendidikan dan Kebudayaan. 2016: 36-37.

[9] Sobandi, Ade. Pengaruh Kompetensi Guru Terhadap Kinerja Mengajarn Guru SMKN Bidang Keahlian Bisnis dan Manajemen di Kota Bandung. Jurnal Manajerial. 2010. Vol. 9, No. 17: 30 .

[10] Astuti, Suhandi. Penerapan Supervisi Akademik Untuk Meningkatkan Kompetensi Guru Dalam Menyusun Administrasi Penilaian Di SD Laboratorium UKSW. Jurnal Scholaria. 2016; Vol. 6 No. 1, Januari: 117.

[11] Hardono, dkk. Kepemimpinan Kepala Sekolah, Supervisi Akademik, dan Motivasi Kerja dalam Meningkatkan Kinerja Guru. Educational Management. 2017. Volume 6, No. 1: 29.

[12] Sihite, Hotnida. Upaya Meningkatkan Kompetensi Profesional Guru Melalui Penerapan Pendekatan Supervisi Kolaboratif Bagi Guru SD Negeri Pinangsori 12 Kecamatan Pinangsori Kab. Tapanuli Tengah Pada Semester Ganjil Tahun Pelajaran 2019/2020. PeTeKa (Jurnal Penelitian Tindakan Kelas dan Pengembangan Pembelajaran). 2019; Vol. 2 No. 2: 83 dan 86.

[13] Snae.Y, dkk. Supervisi Akademik. Jakarta: Kementrian Pendidikan dan Kebudayaan. Direktorat Jenderal Guru dan Tenaga Kependidikan. 2016: 79.

[14] Amanah, Siti, dkk. Handout Diklat Supervisi Pembelajaran IPA. Bandung: P4TK IPA Direktorat Jenderal Guru dan tenaga Kependidikan Kementerian Pendidikan dan Kebudayaan. 2020: 8.

[15] Sutarmin. Peningkatan Kompetensi Profesional Guru Melalui Supervisi Kolaborasi Di SD Negeri Karanggupito 3. Jurnal Pendidikan Tambusai. 2019; Volume 3 Nomor 4: 920.

[16] Widoyoko, Eko Putro. Teknik Penyusunan Instrumen Penelitian. Yogyakarta: Pustaka Pelajar. 2014: 46.

[17] Rianto, Adi. Metodologi Penelitian Sosial dan Hukum. Jakarta: Granit. 2010: 96. 